\title{
Surgical relief of left ventricular outflow obstruction in pediatric hypertrophic cardiomyopathy: The need for a tailored approach
} \author{
Magdi Yacoub, FRS, OM$^{\mathrm{c}, \mathrm{e}}$ \\ From the a Pediatric Cardiac Surgery, The Children's Hospital at Saint Francis, Tulsa, Okla; ${ }^{\text {bPediatric Cardiac }}$ \\ Surgery, Arkansas Children's Hospital, Little Rock, Ark; ${ }^{c}$ Biomedical Engineering and Innovation Laboratory, \\ Aswan Heart Centre, Magdi Yacoub Foundation, Aswan, Egypt; ${ }^{\mathrm{d} C a r d i a c}$ Surgery, Brigham and Women's Hos- \\ pital, Boston, Mass; and ${ }^{\mathrm{e}}$ Harefield Heart Science Centre, National Heart \& Lung Institute, Imperial College \\ London, United Kingdom. \\ Disclosures: Authors have nothing to disclose with regard to commercial support. \\ Received for publication July 30, 2018; revisions received Aug 8, 2018; accepted for publication Aug 16, 2018; \\ available ahead of print Sept 26, 2018. \\ Address for reprints: John M. Karamichalis, MD, FACS, The Children's Hospital at Saint Francis, Pediatric Car- \\ diac Surgery, 6151 South Yale Ave, Suite 2403, Tulsa, OK 74136 (E-mail: jkaramichalis@yahoo.com). \\ J Thorac Cardiovasc Surg 2018;156:2283-4 \\ $0022-5223 / \$ 36.00$ \\ Copyright (c) 2018 by The American Association for Thoracic Surgery \\ https://doi.org/10.1016/j.jtcvs.2018.08.015
}

John M. Karamichalis, MD, FACS, ${ }^{\text {a,b }}$ Heba Aguib, Dr-Ing, ${ }^{\mathrm{c}, \mathrm{e}}$ Alexandra Anastasopulos, MD, ${ }^{\mathrm{d}}$ and

Hypertrophic cardiomyopathy (HCM) is extremely heterogeneous with regard to both genetic origins and phenotypic expressions. ${ }^{1,2}$ The age of onset of the disease has been recently identified as a major determinant of prognosis, phenotype, and association with syndromic features. This has led to the recognition of pediatric $\mathrm{HCM}$ as a specific disease entity ${ }^{1}$ requiring specific management. Left ventricular outflow tract (LVOT) obstruction is a defining feature, ${ }^{3}$ which when severe requires surgical myectomy usually through a transaortic approach. In contrast to adults, the performance of this operation in children is more challenging and requires the use of specific approaches.

The article by the Paris group in this issue of the Journal ${ }^{4}$ is a welcome addition to the literature because it outlines some of these challenges and reports the long-term results of the use of the modified Konno operation in 79 children with the most severe form of HCM varying in age between 1 month and 18 years. The overall results are excellent except in infants with Noonan's syndrome with biventricular obstruction. Perhaps delaying the operation to a minimum age could improve the results. The authors conclude that the modified Konno technique should be considered an alternative approach to transaortic septal myectomy in high-risk patients with extensive hypertrophy and associated right heart obstruction, and in younger patients with a small aortic orifice. A similar surgical approach to HCM septal myectomy through the right ventricle has been recently described for simultaneous relief of right and left ventricular outflow obstruction without perforating the septum ${ }^{5}$ in a tailored technique.

The LVOT performs extremely sophisticated functions, which depend on its complex geometry and dynamism..$^{6-8}$

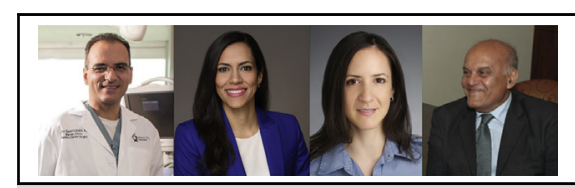

John M. Karamichalis, MD, FACS, Heba Aguib, Dr-Ing, Alexandra Anastasopulos, MD, and Magdi Yacoub, FRS, OM

Central Message

A personalized tailored approach to the operative procedure of relief of LVOT obstruction using sophisticated tools and preoperative imaging may be key to a successful operation.

See Article page 2285.

Changes in the structure and function of the LVOT in HCM are a dynamic process involving most if not all of its component parts, can affect other parts of the left and right ventricle, and are more severe in pediatric patients. The nature and degree of the changes need to be defined preoperatively to enable a personalized surgical approach to restore the sophisticated functions of the LVOT without injuring the surrounding vital structures. The procedure should be tailored to deal with all the varied components of the obstruction, including fibrous trigones, accessory tissues, and papillary muscle fusion. Planning the personalized operation requires a series of tests. Preoperative multimodality imaging, 3-dimensional modeling (Figure 1), and intraoperative transesophageal echocardiography are essential to define the specific abnormalities to be dealt with and assess the repair. The use of currently available and emerging imaging modalities, such as diffusion tensor magnetic resonance imaging, could be applied to define the deranged pattern of myocardial trabeculae and possibly fiber orientation, in individual patients, to further enhance the precision of the operation. In addition, computer simulation with 3-dimensional modeling of the ventricle coupled with application of virtual operations with more detailed analysis of the possible effects on the hemodynamics ${ }^{10}$ and the kinetics of the myocardium may be of value in further refinement of the operation. ${ }^{11}$ The development of instruments to enhance visibility and precision inside the ventricular cavity could be of assistance during operation. 


\section{Left ventricular wall structure}

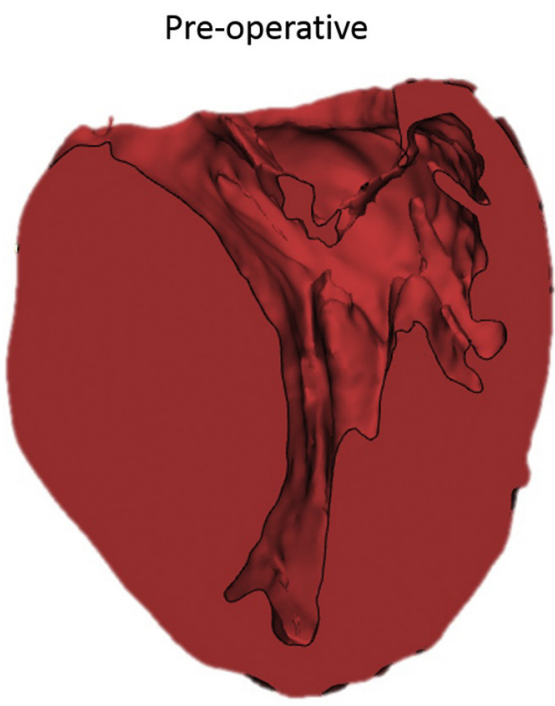

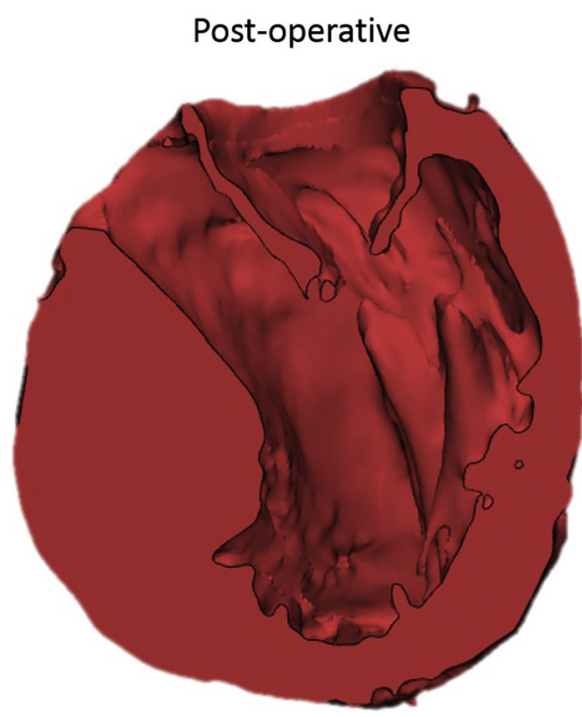

3D anatomical model reconstructed for HOCM patient pre and post operative from End-diastolic phase CT images

FIGURE 1. Preoperative and postoperative 3-dimensional segmentation of the left ventricular wall in a 13-year-old patient with HCM, showing complete relief of outflow obstruction, the site of the septal myectomy, considerable reverse remodeling of the rest of the ventricular wall, and normalization of the left ventricular volume at end diastole. Segmentation by Mohamed Nagy, Biomedical Engineering and Innovation Laboratory, Aswan Heart Centre. 3D, 3-dimensional; HOCM, hypertrophic cardiomyopathy; $C T$, computed tomography.

Tailoring the surgical approach on the basis of the individual patient's anatomy using advanced technology may be key in the success of the operation and personalized medicine.

\section{References}

1. McNally EM. Pediatric cardiomyopathy-another case where children are not small adults. JAMA Cardiol. 2018;3:526.

2. Yacoub MH. Decade in review-cardiomyopathies: cardiomyopathy on the move. Nat Rev Cardiol. 2014;11:628-9.

3. Maron MS, Olivotto I, Zenovich AG, Link MS, Pandian NG, Kuvin JT, et al. Hypertrophic cardiomyopathy is predominantly a disease of left ventricular outflow tract obstruction. Circulation. 2006;114:2232-9.

4. Laredo M, Khraiche D, Raisky O, Gaudin R, Bajorlle F, Maltret A, et al. Long-term results of the modified Konno procedure in high-risk children with obstructive hypertrophic cardiomyopathy. J Thoracic Cardiovasc Surg. 2018;156:2285-94.e2.

5. Borisov KV. Surgery of hypertrophic obstructive cardiomyopathy in patients with severe hypertrophy, myocardial fibrosis, and ventricular tachycardia. Ann Thorac Surg. 2018;106:30-8.
6. Yacoub MH, Kilner PJ, Birks EJ, Misfeld M. The aortic outflow and root: a tale of dynamism and crosstalk. Ann Thorac Surg. 1999;68:S37-43.

7. Davies JE, Hadjiloizou N, Leibovich D, Malaweera A, Alastruey-Arimon J, Whinnett ZI, et al. Importance of the aortic reservoir in determining the shape of the arterial pressure waveform-the forgotten lessons of Frank. Artery Res. 2007; 1:40-5.

8. Yacoub MH, Afifi A, Saad H, Aguib H, ElGuindy A. Current state of the art and future of myectomy. Ann Cardiothorac Surg. 2017;6:307-17.

9. Nielles-Vallespin S, Khalique Z, Ferreira PF, de Silva R, Scott AD, Kilner P, et al. Assessment of myocardial microstructural dynamics by in vivo diffusion tensor cardiac magnetic resonance. J Am Coll Cardiol. 2017;69: 661-76.

10. Torii R, El-Hamamsy I, Donya M, Babu-Narayan SV, Ibrahim M, Kilner PJ, et al. Integrated morphologic and functional assessment of the aortic root after different tissue valve root replacement procedures. J Thorac Cardiovasc Surg. 2012;143:1422-8

11. Lloyd R, Grover S, Parnham SF, Lou PW, Bradbrook C, Yeates L, et al. Preclinical alterations in cardiac energetics amongst sarcomere mutation carriers in hypertrophic cardiomyopathy. J Cardiovasc Magn Reson. 2015; 17:083. 